\title{
How do water table drawdown, duration of drainage and warming influence greenhouse gas emissions from drained peatlands of the Zoige Plateau?
}

\author{
Dan Xue ${ }^{1}$, Huai Chen ${ }^{1}$, Wei Zhan ${ }^{1}$, Xinya Huang ${ }^{1}$, Yixin $\mathrm{He}^{1}$, chuan zhao ${ }^{1}$, Dan Zhu ${ }^{1}$, and \\ Jianliang $\mathrm{Liu}^{2}$ \\ ${ }^{1}$ Chengdu Institute of Biology, Chinese Academy of Sciences, China \\ ${ }^{2}$ Chengdu Institute of Biology, CAS
}

August 14, 2020

\begin{abstract}
As an important soil carbon pool in Qinghai-Tibet Plateau (QTP), alpine peatland are extremely sensitive to global change. Duration of drainage and water table drawdown accelerate peatland degradation due to the soil changed from anaerobic condition to aerobic condition, which may even worsen under climate warming. Hence, the objective of our research was to evaluate the effect of drainage on microbial characteristics, greenhouse gas (GHG) emissions and their influencing factors, and further analyze whether the the variability of GHG emissions increases with warming. The results showed that the influence of water table drawdown on microbial communities were greater than that of duration of drainage. Both the fungal and prokaryotic community compositions varied with water table gradient, and soil microbiota may served as a biomarker to analyze the differences in GHG emissions among three different water table treatments. Intriguingly, the GHG emission decreased with the increase of drainage age, while water table drawdown decreased the emissions of $\mathrm{CO} 2$ and $\mathrm{CH} 4$, and increased the emission of $\mathrm{N} 2 \mathrm{O}$. In addition, high temperature increased $\mathrm{CO} 2$ by $75 \%$ and $\mathrm{N} 2 \mathrm{O}$ by $42 \%$, but not significantly decreased the CH4 emission rates. Structural equation modeling showed that microbe was the primary factor affecting GHG emissions from drained peatlands, especially prokaryotes. In all, this study indicate water table has a greater effect on GHG emissions than duration of drainage, and the variability of GHG emissions increases with warming.
\end{abstract}

\section{INTRODUCTION}

Peatland are an important global carbon pool that contain 1,055 Gt of soil carbon, and covering $3 \%$ of the Earth's land surface (Nichols \& Peteet, 2019). With higher carbon densities than other ecosystems, they release more GHG emissions (Danevčič, Mandic-Mulec, Stres, Stopar, \& Hacin, 2010). In particular, peatlands were destabilized by natural and hunman factors in recent years, such as climate change, land-use change and other disturbances, and more carbon was emitted into the atmosphere (Chen et al., 2014; Ward, Bardgett, McNamara, Adamson, \& Ostle, 2007).

Becase of the special altitude, alpine peatland ecosystem have higher sensitivity to global change (Ise, Dunn, Wofsy, \& Moorcroft, 2008). The peatlands in this area are in a low temperature and anoxia all year round, and climate warming have changed peatlands as a carbon sink to a carbon source (Dise \& Phoenix, 2011). Warming-induced the acceleration of carbon and nitrogen $(\mathrm{C}$ and $\mathrm{N})$ decomposition in peatland, which further exacerbating climate change (Wen et al., 2019). So far, the research on $\mathrm{C}$ and $\mathrm{N}$ cycling of peatland induced by climate warming has most focused on undisturbed peatlands (McPartland et al., 2019; Weedon et al., 2013). In addition, many researchers have explored the response of carbon and nitrogen cycling to water table fluctuation (Cao, Chen, Wu, Zhou, \& Sun, 2018; de Vries et al., 2018; Rhymes et al., 2016; Zhang et 
al., 2018). However, there are relatively few studies on the effects of climate warming on drained peatlands. A recent study found in the period 2020-2100, the impact of emissions from drained peatlands could be as high as $41 \%$ of the GHG emissions budget (Leifeld, Wüst-Galley, \& Page, 2019). Drainage peatlands become hotspots for both $\mathrm{CO}_{2}$ and $\mathrm{N}_{2} \mathrm{O}$ emissions from soils, as well as a minor part of $\mathrm{CH}_{4}$ source or even carbon sink (Saurich, Tiemeyer, Dettmann, \& Don, 2019).

Zoige peatlands is one of the largest alpine peatlands in the world, covered about $4605 \mathrm{~km}^{2}$ area, and store approximately $0.477 \mathrm{Pg}$ of carbon (Chen et al., 2014). Similar to other peatlands (Hooijer et al., 2010; Urbanova \& Barta, 2016), it is currently experiencing ubiquitous warming and intensified anthropogenic activities. Since the 1960s, nearly half of the Zoige peatland have drained due to pasture expansion (Dong, $\mathrm{Hu}$, Yan, Wang, \& Lu, 2010). Meanwhile, global warming had doubled the rate of warming on Tibetan Plateau over the past century (Qiu, 2007).

Anaerobic surface peat changes to aerobic with the soil drainage, which increased in $\mathrm{C}$ and $\mathrm{N}$ decomposition rate (Borken \& Matzner, 2009). The magnitude of GHG emissions and microbial activity increase as soils become oxygenated (Chapuis-Lardy, Wrage, Metay, Chotte, \& Bernoux, 2007; Oertel, Matschullat, Zurba, Zimmermann, \& Erasmi, 2016). Many studies have found that drained peatlands can release a lot of dissolved organic carbon (DOC) (Fenner \& Freeman, 2011; Liu et al., 2019) and $\mathrm{CO}_{2}$ (Gatis et al., 2019). In addition, peatlands drainage significantly reduced the emission of $\mathrm{CH}_{4}$ (Laine et al., 1996), but substantially increased $\mathrm{N}_{2} \mathrm{O}$ fluxes (Martikainen, Nykänen, Crill, \& Silvola, 1993). Drainage changes the biogeochemical and hydrological processes of peatlands and shifting peatland from a carbon sink to a source of GHG emissions (Norberg, Berglund, \& Berglund, 2018; Tiemeyer et al., 2016). Many researches have shown that GHG emissions from soils increase with anthropogenic disturbance (Cai \& Chang, 2020; Peng et al., 2013; Saurich et al., 2019). Global warming can accelerate the decomposition of recalcitrant organic matter and old aged carbon, which resulting in the $\mathrm{C}$ and $\mathrm{N}$ loss from these ecosystems (Craine, Fierer, \& McLauchlan, 2010; Dillon, Wang, \& Huey, 2010). However, how the GHG production and responses to temperature in drained peatland are still uncertain.

Soil microbes play a critical role in the processes involved in the cycling of $\mathrm{C}$ and $\mathrm{N}$, and they are sensitive to environmental changes (Anthony, Crowther, Maynard, van den Hoogen, \& Averill, 2020). It was found that microorganisms are very sensitive to the availability of water and oxygen in wetland ecosystems (Jaatinen, Fritze, Laine, \& Laiho, 2007). Water table drawdown enhances the activities of extracellular enzyme (Wiedermann, Kane, Potvin, \& Lilleskov, 2017), increases microbial biomass(Minick, Mitra, Li, Noormets, \& King, 2019), and thus changes the GHG emissions resulting from microbial activities (Wang et al., 2017; Zhong et al., 2017). As well the vulnerability or resilience of microbial communities to water table drawdown is likely to depend on duration of drainage. In the longterm, microbial structure and function will change due to the shifts in the composition of vegetation, which caused by water table drawdown (Murphy, Laiho, \& Moore, 2009), which will alter (Kwon, Haraguchi, \& Kang, 2013).

Because of the limited data about $\mathrm{C}$ and $\mathrm{N}$ dynamics of alpine peatlands, and together with ubiquitous global change, it may be of great significance to study the $\mathrm{C}$ and $\mathrm{N}$ dynamics in Zoige peatlands. Drainage lead to rapid peatland degradation and carbon losses, and the emissions of GHG are likely to increase further with the climate warming. Therefore, we wanted to answer the following questions in this study: 1) Whether the degradation of peatland caused by drainage change the microbial community? 2) what is the effect of drainage on CHG emission rates in Zoige peatlands? 3) Whether warming further increase the GHG emissions from the drained peatlands? 4) What are the influencing factors of GHG emissions from drained peatlands?

\section{MATERIALS AND METHODS}

\section{Site and soil sampling}

Samples were collected from two sites with different drainage histories in the Ruokeba peatland demonstration

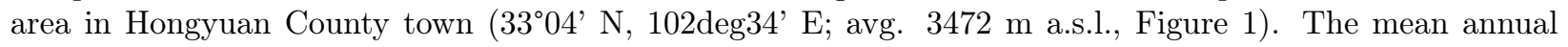
temperature was $1.6 \mathrm{degC}$, and the mean annual precipitation was $760 \mathrm{~mm}$ for the period 1961-2016 (Cao et 
al., 2018). Zoige plateau has experienced significant climate change and human activities in the past 50 years, and temperature increased $0.4 \mathrm{deg} C$ per decade since 1970 (Yang et al., 2014). The plant communities in this area is over $70 \%$ and consists mostly of Grass, Sedge, Gentianaceae, Rosaceae, Ranunculaceae, Leguminosae and Forb.

The long-term drainage site ( $\mathrm{L}$; drainage age $=48$ years) was used as a grazing pasture in the $1970 \mathrm{~s}$, and the ditch is now $0.3-0.5 \mathrm{~m}$ deep and $1-1.5 \mathrm{~m}$ wide. The adjacent short-term drainage site $(\mathrm{S}$; drainage age $=$ 3 years) was drained in 2015 (duration of drainage $=3$ years) to analysis the effect of drainage age on GHG emissions, and the ditch is now 0.3-0.5 $\mathrm{m}$ deep and 0.5-1.0 $\mathrm{m}$ wide.

In July 2018, we sampled a total of six plots that were spaced 2, 10, and $50 \mathrm{~m}$ from the drainage ditch in the short- and long-term drainage sites. $0-15 \mathrm{~cm}$ soil columns were randomly sampled in quadruplicate using an auger at each plot. We used a grid layout to monitor the water table in these sites and collected data at different distances from the two ditches between 2016 and 2018. During the growing season, average water table depths at the short-term site were $-31.38 \mathrm{~cm}(\mathrm{~S} 2),-18.50 \mathrm{~cm}(\mathrm{~S} 10)$, and $-8.13 \mathrm{~cm}$ (S50), while depths at the long-term site were $-31.75 \mathrm{~cm}$ (L2), $-10 \mathrm{~cm}$ (L10), and $-6.13 \mathrm{~cm}$ (L50) (Figure S1). Based on these values, the L2 and S2 treatments were considered as the low water table treatments (L); L10 and S10, intermediate water table treatments (I); and L50 and S50, high water table treatments (H). The collected soil samples were kept at $4 \mathrm{degC}$. Moist soils were sieved through a mesh $(2 \mathrm{~mm})$ to remove impurities and to further homogenize the samples before subdivision for analysis. The soil was separated into three sections: one section was for incubation experiment, one section was stored at $4 \mathrm{deg} \mathrm{C}$ to analyze the physicochemical properties and the last was frozen at $-80 \mathrm{deg} C$ for microbiological analysis.

\section{Soilparameters and microbial commum.ity composition analysis}

Soil parameters including soil water content (\% SWC), $\mathrm{pH}$, total carbon (TC), dissolved organic C (DOC), total dissolved nitrogen (TDN), total nitrogen (TN), soil ammonium $\mathrm{N}\left(\mathrm{NH}_{4}{ }^{+}-\mathrm{N}\right)$, soil nitrate $\mathrm{N}\left(\mathrm{NO}_{3}{ }^{-}-\mathrm{N}\right)$ and microbial biomass $\mathrm{C}$ and $\mathrm{N}$ (MBC and $\mathrm{MBN}$ ) were examined in 24 samples (4 replicates $\mathrm{x} 3$ plots $\mathrm{x}$ 2 sites) before incubation. Soil samples were dried for at least $12 \mathrm{~h}$ at $105 \mathrm{degC}$ to measure SWC; $\mathrm{pH}$ was measured using an acidity meter (Sartorius PB-10, Gottingen,, Germany); TC and TN were determined using an elemental analyzer (Elementar, Langenselbold, Germany); Concentrations of $\mathrm{NH}_{4}{ }^{+}{ }_{-} \mathrm{N}$ and $\mathrm{NO}_{3}{ }^{-}-\mathrm{N}$ were extracted with $2 \mathrm{M} \mathrm{KCl}$ as the extractant and measured using a continuous flow analyzer (San ++ , Skalar, Breda, Netherlands); DOC and TDN were measured using a TOC/TN analyzer (Multi N/C 2100, Analytik, Jena, Germany) based on a water extraction method (Pinsonneault et al., 2016); Chloroform fumigation extraction method were used to detect MBC and MBN (Vance et al., 1987). Aboveground plant biomass of each plots was detected on August 2018, and weighed after oven dring samples for $36 \mathrm{~h}$ at $65 \mathrm{degC}$.

For microbial diversity, about $0.25 \mathrm{~g}$ of each sample soil was used for DNA extraction by PowerSoil DNA Isolation Kit (MoBio Laboratories, Carlsbad, CA, USA). High- throughput sequencing was carried out on the Illumina MiSeq platform using the MiSeq V2 Reagent Kit (Illumina, Inc., San Diego, CA), after amplified by prokaryote and fungi primer pairs 515F/909R and ITS4/gITS7F(Baker et al., 2003; Ihrmark et al., 2012). The sequencing data was trimed via QIIME pipeline (http://qiime.org/tutorials/tutorial.html). For detailed analysis procedures refered to Xue et al. (2016). Taxonomy was assigned using the Greengenes database for prokaryote and the Unites database for fungi. 1,266,722 and 1,298,041 assembled paired-end reads were identified in 24 samples through sequencing of $16 \mathrm{~S}$ rRNA gene and ITS2 amplicons, respectively. Subsampling (17,150 for prokaryote and 18,170 for fungi, the lowest) was performed to calculate microbial diversity. The sequencing datas have been deposited in Sequence Read Archive (SRA) in NCBI under the accession numbers SRP255927 and SRP256039.

\section{Soil incubation experiment and GHG measurements}

The soil incubation experiment was conducted under aerobic condition with two temperatures (8degC and $18 \mathrm{deg} C$ ) and four replicates (2 temperatures $\mathrm{x} 4$ replicates $\mathrm{x} 3$ plots $\mathrm{x} 2$ sites $=48$ ). Peat was sieved by a 2 $\mathrm{mm}$ mesh sieve, and the remaining coarse roots and stones were carefully removed and discarded. The soil was stored at $8 \mathrm{deg} \mathrm{C}$ (Average temperature in growing season) in the dark for one week of pre-incubation 
before the experiment. $20 \mathrm{~g}$ soil was puted in a $100 \mathrm{ml}$ glass bottle, sealed with rubber stopper and flushed with $\mathrm{CO}_{2}$-free air for $8 \mathrm{~min}$ to maintain aerobic environment. During the incubation period of 35 days, $5 \mathrm{ml}$ headair was collected every $24 \mathrm{~h}$ for $\mathrm{CO}_{2}, \mathrm{CH}_{4}$ and $\mathrm{N}_{2} \mathrm{O}$ concentration measurement. The GHG emissions from the soil of peatland were detected on day 1, 3, 5, 7, 14, 21, 28 and 35 using gas chromatography (Agilent 7890A, Agilent Co., USA). After each sampling, the headspace was flushed with $\mathrm{CO}_{2}$-free air again to fully remove the accumulated GHG. The greenhouse gases emissions were calculated as (Liu et al., 2016):

$$
F=\frac{\text { PPM. } M_{0}}{22.4} \cdot \frac{T_{0}}{T} \cdot \frac{P}{P_{0}} \cdot \frac{V_{0}}{m} \cdot \frac{1}{d}
$$

where $\mathrm{F}\left(\mu \mathrm{g} \cdot \mathrm{d}^{-1} \mathrm{~g}^{-1}\right)$ is the rate of greenhouse gas eemission; $\mathrm{M}_{0}$ : molar mass of $\mathrm{CO}_{2}, \mathrm{CH}_{4}$ and $\mathrm{N}_{2} \mathrm{O}$; T and $\mathrm{P}$ : temperature and atmosphere pressure in headspace of the bottle; $\mathrm{T}_{0}$ and $\mathrm{P}_{0}$ : standard temperature and atmosphere pressure; $\mathrm{V}_{0}$ : the bottle capacity is $100 \times 10^{-6} \mathrm{~m}^{3} ; \mathrm{m}$ : the weight of the dry soil; d: the incubation time is $1 \mathrm{~d}$. TDN and DOC were analyzed after 35-day incubation.

\section{Data analysis}

NMDS and PERMANOVA based on Bray-Curtis distance matric were used to evaluate the overall structural alteration of prokaryote and fungi. Random forest analysis was performed to select the important features that may contribute to the differences in GHG emissions among three different water table treatments (Breiman, 2001). Cross-validation was used for feature selection. Functional profiles of prokaryotic taxa were annotated using FAPROTAX v.1.1 (Louca, Parfrey, \& Doebeli, 2016) to perdict the process of the carbon, hydrogen, nitrogen, phosphorus and sulfur cycle of environmental samples.

The temperature sensitivity of the GHG emission is defined as the variation of GHG emission response to $10^{\circ} \mathrm{C}$ temperature gradient. Varied DOC and TDN represented the changes of DOC and TDN concentrations in the incubation period. The difference of GHG emission, DOC and TDN concentration between two temperatures calculated by $t$-Test. Differences in soil microbial compositions, GHG emissions, $\mathrm{Q}_{10}$, varied DOC and TDN concentrations based on duration of drainage and water table drawdown were assessed using multi-factor analysis of variance (ANOVA) in SPSS 21.0 (IBM, Armonk, NY, USA). Correlation analysis was performed to evaluate the impact of varied DOC and TDN concentration, soil properties and microbial characteristics on GHG emission rate using R 3.5.1. (R Development Core Team, 2018).

Direct and indirect contributions of water table, drainage age, soil properties and microbial characteristics to GHG emissions used by Structural equation modeling (SEM) (Grace, 2006). The SEM of differet factors affecting GHG emission was developed from a priori models based on literature, knowledge and correlation analysis data (Figure S2). The prokaryotic and fungal community dissimilarity were obtained by NMDS of the Bray-Curtis distance matrix, and the first axes (NMDS 1) were used in the subsequent SEM analysis. SEM analysis was performed by AMOS 25.0 sofeware (AMOS IBM, USA) using the robust maximum likelihood evaluation method. The SEM fitness was evaluted by the indexes of a non-significant chi-square test (df $>$ $5 ; p>0.05)$, the root mean square error of approximation (RMSEA $<0.05$ ) and the goodness of fit index (GFI) (Byrne, 2016).

SPSS 21.0 (IBM, Armonk, NY, USA), R 3.5.1. software (R Development Core Team, 2018) and GraphPad Prism 8.0.2 (GraphPad Software, San Diego, CA, USA) were used to all statistical analysis and charting. $p<0.05$ was considered significant differences.

\section{RESULTS}

\section{Microbial characteristics}

\subsubsection{Variation in the community structures of prokaryotes and fungi}

The microbial diversities of soils with different water level in short- and long-term drainage sites were characterized through partial 16S rRNA and ITS2 region gene sequencing. A total of 1,266,722 and 1,298,041 
highquality sequences were analyzed for prokaryote and fungi, respectively. The prokaryotic and fungal community structures of different treatments were evaluated according to $\beta$-diversity using NMDS analysis and PERMANOVA test (Figure $2 \mathrm{a}$ and $2 \mathrm{~b}$ ). We found that water table and drainage age have significant effects on prokaryotic structure (PERMANOVA, $p<0.001$ and $p=0.008$ ) and fungal (PERMANOVA, $p<0.001$ and $p=0.002$ ) communities in Zoige peatlands. Additionally, both the prokaryotic and fungal communities of low-water table treatments (LWT: L2 and S2) was significantly different from that in intermediate water table treatments (IWT: L10 and S10) and high water table treatments (HWT: L50 and S50) (Figure 2a and 2b, PERMANOVA, $p<0.001$ for both), but the difference of prokaryotic and fungal communities between IWT and HWT were also significant ( $p=0.006$ and $p=0.008$, respectively). The differences caused by water table were significantly greater than those associated with drainage age (Figure $2 \mathrm{a}$ and $2 \mathrm{~b}$ ), indicating that the influence of water table on microbial community structures was greater than that of drainage age.

\subsubsection{Changes in dominant phyla of prokaryotes and fungi}

The 12 most abundant prokaryotic phyla (relative abundance higher than 1\%) and 6 fungal phyla (>0.1\%) were selected to evaluate the effects of water table drawdown and drainage age on the most significant taxonomic shifts in the soil microbial community of degraded peatlands (Figure 2c and 2d, Table S1). We observed the relative abundances of all prokaryotic and fungal phyla were changed significantly with water table $(p<0.05$ for all, Table S1). Remarkably, the relative abundances of Proteobacteria, Acidobacteri, Actinobacteria, Basidiomycota and Zygomycota significantly increased, whereas Chloroflexi, Bacteroidetes, Crenarchaeota and Ascomycota markedly decreased with the water table drawdown (Figure 2c and 2d). Compared with short-term drainage, Actinobacteria, Gemmatimonadetes and Nitrospirae showed more relative abundance in long-term drainage sites, while the higher relative abundances of Bacteroidetes, Crenarchaeota, Chytridiomycota and Glomeromycota were observed in the short-term drainage sites $(p<0.05$ for all, Table S1).

\subsubsection{Soil microbiota as biomarkers}

We subsequently analyzed whether we could discriminate samples with different water table based upon the microbiota composition using a random-forest machine learning analysis (Zhang et al., 2019). We performed a ten-fold cross-validation to evaluate the importance of indicator prokaryotic classes. We detected 14 classes as biomarker taxa when the cross-validation error curve was lowest (Figure 3a). Among theses, 8 classes had higher relative abundance in intermediate and high water table treatments (IWT and HWT), while 6 classes showed higher relative abundance in low-water table treatments (LWT; Figure 3b). This result demonstrates that soil microbial biomarker can be used as one of the important indexes to evaluate peatland degradation.

\subsubsection{Functional annotation and distribution of prokaryotic community}

FAPROTAX was further applied to evaluate the influence of water table on soil $\mathrm{C}$ and $\mathrm{N}$ processes (Figure 3c). A total of 69 functional pathways were obtained from 1688 OTUs. We found no significant difference in the relative abundances of functional pathway between the IWT and HWT, so we further analyzed the difference between the LWT and IWT and HWT treatments, and found that there were 42 functional pathways with significant differences (Figure 3c). The results showed that the low water table treatments had higher nitrate denitrification, nitrite denitrification, nitrate reduction and respiration, but had lower nitrite ammonification and nitrogen respiration. This imply that more $\mathrm{NO}_{3}{ }^{-}$were used for denitrification in LWT than IWT and HWT. In addition, we found the relative abundances of many carbon metabolism-related pathways, including methanogenesis, methanotrophy, fermentation, hydrocarbon degradation and etc., were significantly higher in IWT and HWT than in LWT.

\section{GHG emission and itstemperature sensitivity}

$\mathrm{CO}_{2}$ and $\mathrm{N}_{2} \mathrm{O}$ emission rates began low, peaked at about day 21, and kept a relative subsequently during the 35-day incubation. In addition, we found that $10{ }^{\circ} \mathrm{C}$ warming brought forward the peak of $\mathrm{CO}_{2}$ and $\mathrm{N}_{2} \mathrm{O}$ emissions by a week (Figure S3).

\subsubsection{GHG emission variation with water table and drainage age}


The average GHG emission rate and its response to warming changed significantly with water table and drainage age $\left(p<0.01\right.$ for all, Table S2). At $8{ }^{\circ} \mathrm{C}$ and $18^{\circ} \mathrm{C}$, the average rates of $\mathrm{CO}_{2}, \mathrm{CH}_{4}$ and $\mathrm{N}_{2} \mathrm{O}$ emissions from different water table treatments were significantly higher at short-term drainage sites than long-term drainage sites, respectively (Figure 4 and Table S2). At the same time, we also found that $\mathrm{CO}_{2}$ and $\mathrm{CH}_{4}$ emission rates were all significantly higher under IWT conditions than the other conditions at both two temperatures, while the $\mathrm{N}_{2} \mathrm{O}$ emission rates were significantly higher under LWT conditions (Figure 4 and Table S2). Similar to the results of FAPROTAX analysis, the GHG emission decreased with the increase of drainage age, and water table drawdown reduced the $\mathrm{CO}_{2}$ and $\mathrm{CH}_{4}$ emission rates, but increased $\mathrm{N}_{2} \mathrm{O}$ emission rates.

\subsubsection{GHG emission variation with warming}

Warming significantly increased the average rates of $\mathrm{CO}_{2}$ and $\mathrm{N}_{2} \mathrm{O}$ emissions of all treatments at short-term and long-term drainage sites, but slightly decreased the $\mathrm{CH}_{4}$ emission rates, even not significantly (Figure 4). We found the average $\mathrm{CO}_{2}$ emission rate at short-term drainage site was $36.34 \pm 19.21 \mu \mathrm{g} \mathrm{g}^{-1} \mathrm{~d}^{-1}$ at 8 ${ }^{\circ} \mathrm{C}$ and $63.27 \pm 31.18 \mu \mathrm{g} \mathrm{g} \mathrm{g}^{-1} \mathrm{~d}^{-1}$ at $18{ }^{\circ} \mathrm{C}$, and significantly increased by $74.11 \%$ with ten degree warming, while the average $\mathrm{CO}_{2}$ emission rate at long-term drainage site was $24.25 \pm 10.21 \mu \mathrm{g} \mathrm{g}^{-1} \mathrm{~d}^{-1}$ at $8{ }^{\circ} \mathrm{C}$ and $42.57 \pm 10.75 \mu \mathrm{g} \mathrm{g}^{-1} \mathrm{~d}^{-1}$ at $18{ }^{\circ} \mathrm{C}$, which significantly increased by $75.55 \%$ with $10{ }^{\circ} \mathrm{C}$ warming. In addition, we also found warming significantly increased average $\mathrm{CO}_{2}$ emission rate of $\mathrm{LWT}$ conditions by $91.14 \%$ from $19.46 \pm 6.13 \mu \mathrm{g} \mathrm{g}^{-1} \mathrm{~d}^{-1}$ of $8{ }^{\circ} \mathrm{C}$ to $37.78 \pm 8.66 \mu \mathrm{g} \mathrm{g}^{-1} \mathrm{~d}^{-1}$ of $18{ }^{\circ} \mathrm{C}$, IWT conditions by $56.44 \%$ from $46.60 \pm$ $13.20 \mu \mathrm{g} \mathrm{g} \mathrm{g}^{-1} \mathrm{~d}^{-1}$ of $8{ }^{\circ} \mathrm{C}$ to $72.90 \pm 28.88 \mu \mathrm{g} \mathrm{g} \mathrm{g}^{-1} \mathrm{~d}^{-1}$ of $18{ }^{\circ} \mathrm{C}$, and HWT conditions by $93.60 \%$ from 24.83 $\pm 3.56 \mu \mathrm{g} \mathrm{g}^{-1} \mathrm{~d}^{-1}$ of $8{ }^{\circ} \mathrm{C}$ to $48.07 \pm 5.64 \mu \mathrm{g} \mathrm{g}^{-1} \mathrm{~d}^{-1}$ of $18{ }^{\circ} \mathrm{C}$. The results of temperature sensitivity $\left(\mathrm{Q}_{10}\right)$ of soil respiration also further proved that the sensitivity of IWT conditions to temperature were less than the other conditions (Figure S4).

\section{Variation of DOC and TDN concentration during incubation}

Compared with the soil before incubation, the variations of DOC and TDN concentrations after incubation showed different patterns (Figure 5). While TDN concentration increased, DOC concentration decreased with the water table drawdown at both short-term and long-term drainage sites during incubation $(p<$ 0.001 for all; Figure 5 and Table S3). The DOC concentration of different water table treatments at shortterm drainage site were significantly higher than long-term drainage site, respectively $(p<0.001$; Table S3). Warming decreased the DOC concentration of all treatments $(p<0.05$ for all $)$, but only significantly increased TDN concentration of LWT conditions $(p<0.05$; Figure 5$)$.

\section{The influence factors ofGHG emissions}

The average rates of $\mathrm{CHG}$ emissions during the incubation period was expressed in $\mathrm{CO}_{2}, \mathrm{CH}_{4}$ and $\mathrm{N}_{2} \mathrm{O}$. $\mathrm{CO}_{2}$ and $\mathrm{CH}_{4}$ were positively correlated with DOC concentration under $8{ }^{\circ} \mathrm{C}$ and $18{ }^{\circ} \mathrm{C}(\mathrm{r}=0.555, \mathrm{r}=$ 0.483 for $\mathrm{CO}_{2} ; \mathrm{r}=0.725, \mathrm{r}=0.555$ for $\mathrm{CH}_{4} ; p<0.05$ for all), and were negatively correlated with TDN (r $=-0.495, \mathrm{r}=-0.505$ for $\mathrm{CO}_{2} ; \mathrm{r}=-0.449$ for $\mathrm{CH}_{4}$ at $8{ }^{\circ} \mathrm{C} ; p<0.05$ for all; Figure $6 \mathrm{a}, 6 \mathrm{c}$ and $\left.6 \mathrm{~b}, 6 \mathrm{~d}\right)$. No linear relationship was found among $\mathrm{N}_{2} \mathrm{O}$ and DOC, but $\mathrm{N}_{2} \mathrm{O}$ were correlated positively with TDN under $8{ }^{\circ} \mathrm{C}(\mathrm{r}$ $=0.459, p<0.05 ;$ Figure $6 \mathrm{e}$ and $6 \mathrm{f})$.

Spearman's correlation analysis were used to further evaluate microbial influences on the GHG emissions, DOC and TDN concentrations (Figure 7). An interesting result was found that the relationship between the dominant microbial phyla (11 most abundant prokaryotic phyla and 5 fungal phyla) and carbon and nitrogen mineralization showed opposite trends (Figure 7). Firmicutes, Chloroflexi, Chlorobi, Bacteroidetes and Crenarchaeota of prokaryotic phyla and Ascomycota, Chytridiomycota and Glomeromycota of fungal phyla showed a positive relationship with carbon mineralization (including $\mathrm{CO}_{2}, \mathrm{CH}_{4}$ and DOC), but a negative relationship with nitrogen mineralization (including $\mathrm{N}_{2} \mathrm{O}$ and TDN). Proteobacteria, Acidobacteria, Planctomycetes and Gemmatimonadetes of prokaryotic phyla and Basidiomycota, Zygomycota of fungal phyla showed a negative relationship with carbon mineralization (including $\mathrm{CO}_{2}, \mathrm{CH}_{4}$ and DOC), but a positive relationship with nitrogen mineralization (including $\mathrm{N}_{2} \mathrm{O}$ and TDN). 
Finally, SEM was applied to access the direct and indirect effects of water table, drainage age, soil properties and soil prokaryotic and fungal communities on GHG emissions (Figure 8). Drainage can directly influenced $\mathrm{CO}_{2}$ and $\mathrm{N}_{2} \mathrm{O}$ emissions, with little or no directly effect on $\mathrm{CH}_{4}$ (Figure 8). Water table showed a directly negative influence on $\mathrm{N}_{2} \mathrm{O}$, with little or no directly effect on $\mathrm{CO}_{2}$ and $\mathrm{CH}_{4}$. Drainage age were directly negative related to $\mathrm{CO}_{2}$, with little or no directly effect on $\mathrm{CH}_{4}$ and $\mathrm{N}_{2} \mathrm{O}$. Drainage can indirectly affected GHG emissions by directly influenced plant biomass, TC, TN, DON, SWC, $\mathrm{NH}_{4}{ }^{+}-\mathrm{N}$, microbial C:N and soil prokaryotic and fungal communities (Figure 8). Prokaryotic community showed a directly positive associated with $\mathrm{CO}_{2}, \mathrm{CH}_{4}$ and $\mathrm{N}_{2} \mathrm{O}$ emissions (Figure 8). SEM suggested that prokaryotic community exhibited a larger impact on GHG emissions than fungal community (Figure 8).

\section{DISCUSSION}

\section{Microbial characteristics varied in relation toduration ofdrainage and water table draw- down}

The response of microbes to drainage is likely to depend on peatland type, the alteration of water table fluction, and the extent of spatiotemporal variation (Andersen, Chapman, \& Artz, 2013; Krista Jaatinen et al., 2008; Minick et al., 2019; Peltoniemi, Fritze, \& Laiho, 2009). Our study found that both water table and drainage age significantly affected the microbial community structure and compositions (Figure 2), which was consistent with many studies (Jaatinen et al., 2007; Urbanova \& Barta, 2016). Drainage can directly lead to water table drawdown in peatlands, resulting in persistent aerobic conditions (Holden, Chapman, Lane, \& Brookes, 2006), while with long-term drainage may further change the vegetation composition, thus affecting microbial composition and function (Miller, Benscoter, \& Turetsky, 2015; Urbanova \& Barta, 2016). Our results showed that water table drawdown significantly increased the relative abundances of Proteobacteria, Acidobacteria, Actinobacteria and Basidiomycota (Figure 2c and 2d). In oxic conditions, Members of Proteobacteria (Di Lonardo, De Boer, Klein Gunnewiek, Hannula, \& Van der Wal, 2017), Acidobacteria(Dedysh, 2011), Actinobacteria (Goodfellow \& Williams, 1983) and Basidiomycota (Ludley \& Robinson, 2008) are considered to be the principal decomposers of soil organic matter, that can degrade recalcitrant organic materials (e.g. lignin, cellulose and humic materials) (Chen et al., 2018; Pankratov, Dedysh, \& Zavarzin, 2006). So these microbes play an important role in GHG emissions, and this results consistent with previous research (Schimel \& Gulledge, 1998). In addition, we also found long-term drainage significantly increased the abundance Actinobacteria of compared to short-term drainage. Relevant studies have found that Actinobacteria are more sensitive to long-term water table drawdown than short-term water table drawdown(Jaatinen et al., 2008; Peltoniemi et al., 2009).

Microbes are ubiquitous and mediate the macroscopic characteristics of the ecosystems (Thompson, Johansen, Dunbar, \& Munsky, 2019). Because of the complexity of microbial communities make it necessary to explore functional relationships between specific microbes and ecosystem characteristics. Here, we have used machine learning techniques to find that specific microbial taxa could be used as one of the important indexes to evaluate peatland degradation. The relative abundance of 4 classes of the phylum Proteobacteria were significantly higher in the LWT compared to IWT and HWT (Figure 3b). As the members of Proteobacteria are involved in bacteriochlorophyll-dependent photosynthesis, they also considered to be the major decomposers of soil organic matter, and showed important role in nutritionally limited or arid environments (Ren et al., 2018). In addition, as an important member of Deltaproteobacteria, methanotroph can effectively oxidize methane in nature (Hanson \& Hanson, 1996). In consistent with other studies (Cao et al., 2018; Siljanen, Saari, Bodrossy, \& Martikainen, 2012; Zhong et al., 2020), we also found the relative abundance of Deltaproteobacteria increased with water table drawdown.

\section{Influence of duration of drainage and water table on GHG emissions}

The emissions of $\mathrm{CO}_{2}, \mathrm{CH}_{4}$ and $\mathrm{N}_{2} \mathrm{O}$ were significantly different between short-term drainage sites and long-term drainage sites (Figure 4 and Table S2). The long-term drainage peatlands are less suitable for microbial use compared with short-term drainage peatlands because of the poor quality of organic matter and low decomposability due to drainage over many decades of grazing history (Andersen et al., 2013; Leifeld, 
Steffens, \& Galego-Sala, 2012; Urbanova \& Barta, 2016). So far, few studies have examined the impact of duration of drainage on GHG emissions of peatland. Most researches have focused on the effect of drainage on GHG emissions in disturbed peatland compared to natural peatland (Cao et al., 2018; Maljanen, Hytönen, \& Martikainen, 2001; Nieveen, Campbell, Schipper, \& Blair, 2005; Zhou, Cui, Wang, \& Li, 2017), or the effect of the water table drawdown on GHG emissions due to drainage (Chen, Borken, Stange, \& Matzner, 2012; Hou et al., 2013; Laiho, Silvan, Cárcamo, \& Vasander, 2001; Saurich et al., 2019; Wang, Siciliano, Helgason, \& Bedard-Haughn, 2017). Kang et al. (2018) showed that $\mathrm{N}_{2} \mathrm{O}$ flux was found to be inconsistent under drought conditions, which may be caused by SOC variations by drought. This is in accordance with our results, We found $\mathrm{N}_{2} \mathrm{O}$ emission in long-term drained peatland was lower than that in short-term drained peatland (Figure 4). Huang, Zou, Zheng, Wang, and Xu (2004) found long-term drought conditions may induced the SOC to be recalcitrant, indicating a reduced supply of organic carbon for microbial activity. Therefore, nitrification and denitrification processes were probably inhibited to produce less $\mathrm{N}_{2} \mathrm{O}$ under the long-term drought conditions.

Many researches have found that water table drawdown caused by drainage make peatlands into sources for $\mathrm{CO}_{2}$ and $\mathrm{N}_{2} \mathrm{O}$, whereas $\mathrm{CH}_{4}$ emission is known to decrease(Cao et al., 2018; Saurich et al., 2019; Tiemeyer et al., 2016). In contrast, Knorr, Glaser, and Blodau (2008) and Muhr, Höhle, Otieno, and Borken (2011) found the emissions of $\mathrm{CO}_{2}$ from minerotrophic fen peatland had no change after water table drawdown. In accordance with other previous researches (Hou et al., 2013; Maljanen et al., 2001; Regina, Silvola, \& Martikainen, 1999), we also found the $\mathrm{N}_{2} \mathrm{O}$ emission increased with the water table drawdown. The nitrogen cycle of peatland soil is very sensitive to the fluctuation of water table (Pal, Stres, Danevčič, Leskovec, \& Mandic-Mulec, 2010). It is well known that soil nitrate is reduced to $\mathrm{N}_{2}, \mathrm{NO}$ and $\mathrm{N}_{2} \mathrm{O}$ through microbial processes (Knowles, 1982). $\mathrm{N}_{2}$ is the end product under anaerobic conditions, while $\mathrm{N}_{2}$ generally replaced by $\mathrm{N}_{2} \mathrm{O}$ at higher oxygen levels (Weil \& Brady, 2017). The results of FAPROTAX also further supported our result, which we found had higher nitrous oxide denitrification, nitrate denitrification, nitrite denitrification, nitrate reduction and respiration, but had lower nitrite ammonification and nitrogen respiration (Figure 3c). In addition, we also found that multiple carbon metabolism-related pathways were significantly higher in IWT and HWT than those of LWT, which was partly supports the results of the carbon emissions (Figure 3c and Figure 4). Freeman, Lock, and Reynolds (1992) and Kwon et al. (2013) pointed out that water table drawdown changes anaerobic surface peat into aerobic, increasing the decomposition rates, microbial activity and aerobic respiration, and then increasing $\mathrm{CO}_{2}$ emissions. However, our results showed that $\mathrm{CO}_{2}$ emissions first increased and then decreased along the water table gradient. Similarly, Laiho (2006) showed that short-term water level drawdown increased $\mathrm{CO}_{2}$ emissions, but the longterm changes of the water level drawdown caused by the drought decreased the $\mathrm{CO}_{2}$ emissions of peatland. Hou et al. (2013) also found that water depth of $5 \mathrm{~cm}$ below surface increased the $\mathrm{CO}_{2}$ emission of peatlands, but the continued water table drawdown was no significant influenced or even decreased the $\mathrm{CO}_{2}$ emission. Swails et al. (2018) further proved that degradation of soil organic matter quality and nutrients associated with drainage may decrease substrate driven $\mathrm{CO}_{2}$ production from peat decomposition. Therefore, water table drawdown increased the emissions of $\mathrm{CO}_{2}$, but this impact maybe offset by long-term drought.

\section{Influence of temperature on GHG emissions}

Our study results consistent with previous studies, which found warming increased $\mathrm{CO}_{2}$ (Laine, Makiranta, et al., 2019) and $\mathrm{N}_{2} \mathrm{O}$ emissions (Cui et al., 2018; Duval \& Radu, 2018), but have no significant impact on CH4 emission (Johnson, Pypker, Hribljan, \& Chimner, 2013; Pearson et al., 2015). As for the impact of temperature on $\mathrm{CO}_{2}$, it is now generally accepted that warming can significantly increase $\mathrm{CO}_{2} \mathrm{emissions}$ in both drained and undrained peatlands (Hopple et al., 2020; Laine, Makiranta, et al., 2019; Salm, Kimmel, Uri, \& Mander, 2009). However, warming appears to have a complex impact on the emission of $\mathrm{CH}_{4}$ from peatlands (Yang et al., 2014). Turetsky et al. (2008) found a positive correlation between warming and $\mathrm{CH}_{4}$ emissions, some reported a negative relationship (Eriksson, Öquist, \& Nilsson, 2010; Peltoniemi et al., 2016), and while some other studies have showed no effect (Laine, Mehtatalo, Tolvanen, Frolking, \& Tuittila, 2019; Pearson et al., 2015). Recenly, many studies have found that warming effect on CH4 emissions varied with the fluction of water table (Laine, Makiranta, et al., 2019; Peltoniemi et al., 2016; Yang et al., 2014). Gill, Giasson, 
Yu, and Finzi (2017) and Munir and Strack (2014) reported that warming increased the $\mathrm{CH}_{4}$ emisssion in water-saturated conditions, while the opposite phenomenon has been found from drier hummocks. This is partly consistent with our research, we only found that warming increased $\mathrm{CH}_{4}$ emission of HWT conditionin short-term drained peatlands, although not significant. Peltoniemi et al. (2016) concluded that the effect of warming under different moisture conditions on the activity and community of microorganisms regulating the methane cycle are not directly.

Consisitent with other ecosystems, for example alpine swamp meadow (Chen et al., 2017), high arctic tundra (Gong, Wu, Vogt, \& Le, 2019) and subarctic tundra (Voigt, Lamprecht, et al., 2017), we found that warming increased $\mathrm{N}_{2} \mathrm{O}$ emissions with different water table treatments in both short-term and long-term drained peatlands at seasonal frozen soil. Butterbach-Bahl et al. (2013) reported that denitrification and consequently $\mathrm{N}_{2} \mathrm{O}$ emissions have high temperature sensitivity. The emission of $\mathrm{N}_{2} \mathrm{O}$ is controlled by of mineral nitrogen availability and influenced by microbial nitrification and denitrification processes (Bouwman, 1990). N mineralization from SOM can be accelerated by warming and leaching of nitrate and ammonium may occur (Bai et al., 2013). Thus, increased soil temperature promoted $\mathrm{N}_{2} \mathrm{O}$ emissions via denitrification(Voigt, Marushchak, et al., 2017). In addition, we also found $\mathrm{Q}_{10}$ values for GHG emissions were all lowest in IWT conditions (Figure S4). This indicates that water table is also an important index affecting the temperature sensitivity of GHG.

\section{The role of biogeochemical factors in GHG emissions}

Many researches have showed that drainage affected the processes of the carbon $(\mathrm{C})$ and nitrogen $(\mathrm{N})$ mineralization of peatland, and thus changed its $\mathrm{C}$ and $\mathrm{N}$ sink and sources function (Chen et al., 2012; Chimner, Pypker, Hribljan, Moore, \& Waddington, 2017; Laine, Makiranta, et al., 2019; Zhang et al., 2020). The fluction of water table can directly affect soil biogeochemical properties, including soil basic physical and chemical properties, soil substrate, microbial community and enzyme activity, which lead to the change of GHG emissions (de Vries et al., 2018; Mpamah, Taipale, Rissanen, Biasi, \& Nykanen, 2017; Swails et al., 2018; Wen et al., 2019). The concentration of DOC and TDN are the balance between soil organic matter production and soil microbial consumption, and DOC and TDN will be further decomposed and discharged in the form of CHG (van den Berg, Shotbolt, \& Ashmore, 2012). Therefore, DOC and TDN concentration in soil can reflect carbon and nitrogen loss (Boothroyd, Worrall, \& Allott, 2015). The results of our study found DOC and TDN concentration were strongly correlated with $\mathrm{CO}_{2}$ and $\mathrm{CH}_{4}$ emissions, while no linear relationship was found between $\mathrm{N}_{2} \mathrm{O}$ and DOC, $\mathrm{N}_{2} \mathrm{O}$ was only correlated positively with TDN (Figure 6). This suggests that soil substrate availability is crucial in GHG emission from soil. We further analyzed the relationship between soil microorganisms and substrate availability and GHG emission. An interesting result was found that some microbial taxa were contribute significantly to carbon mineralization, and others contribute significantly to nitrogen mineralization (Figure 7). Soil microorganisms affect the mineralization of soil organic $\mathrm{C}$ and $\mathrm{N}$ by secreting extracellular enzymes (Chapman, Cadillo-Quiroz, Childers, Turetsky, \& Waldrop, 2017; Schnecker et al., 2015). Abatenh, Gizaw, Tsegaye, and Genene (2018) reported that microbial processes have a central role in GHG emissions and specific functional microorganisms are responsible for the related biochemical processes, and possibly a rapid response to climate change. In addition, SEM was used to analyze the impact of environmental factors on the emission of CHG, and it was found that the prokaryotic microbial community had the greatest impact on GHG, which also further supported the important role of microorganisms in soil GHG emissions (Singh, Bardgett, Smith, \& Reay, 2010).

\section{CONCLUSION}

The emissions of $\mathrm{CO}_{2}, \mathrm{CH}_{4}$ and $\mathrm{N}_{2} \mathrm{O}$ response to drainage is inconsistent. $\mathrm{CO}_{2}$ and $\mathrm{CH}_{4}$ emission rates first increased and then decreased along the water table drawdown gradient, while $\mathrm{N}_{2} \mathrm{O}$ increased along the water table gradient. The emissions of $\mathrm{CO}_{2}, \mathrm{CH}_{4}$ and $\mathrm{N}_{2} \mathrm{O}$ from different water table treatments were significantly higher at short-term drainage sites than long-term drainage sites. The results of FAPROTAX analysis also supported this perspective. In addition, warming significantly increased the average rates of $\mathrm{CO}_{2}$ and $\mathrm{N}_{2} \mathrm{O}$ emissions of all treatments at short-term and long-term drainage sites, but not significantly decreased the $\mathrm{CH}_{4}$ emission rates. The $\mathrm{Q}_{10}$ values of GHG emissions were lowest in IWT conditions compared 
to other conditions. Microbial community composition was the primary factor affecting GHG emissions from peatlands, especially prokaryotes. Collectively, Our results further reveal the mechanism of climate change and human activities on the emisssions of GHG in alpine peatland ecosystem, which can provide support for the sustainable management of alpine peatland in the future.

\section{ACKNOWLEDGEMENTS}

This study was supported by the Strategic Priority Research Program of the Chinese Academy of Sciences (XDA2005010404), Key R \& D Program of Sichuan Province (2020YFS0024), the Chinese Academy of Sciences Light of West China Program (2018XBZG_XBQNXZ_B_008) and the National Natural Science Foundation of China (91851108).

\section{DATA AVAILABILITY STATEMENT}

The data used in this study can be obtained from the corresponding author on reasonable request.

\section{REFERENCES}

Abatenh, E., Gizaw, B., Tsegaye, Z., \& Genene, T. (2018). Microbial Function on Climate Change - A Review. Environment Pollution and Climate Change, 02 . doi:10.4172/2573-458X.1000147

Andersen, R., Chapman, S. J., \& Artz, R. R. E. (2013). Microbial communities in natural and disturbed peatlands: A review. Soil Biology and Biochemistry, 57, 979-994. doi:10.1016/j.soilbio.2012.10.003

Anthony, M. A., Crowther, T. W., Maynard, D. S., van den Hoogen, J., \& Averill, C. (2020). Distinct Assembly Processes and Microbial Communities Constrain Soil Organic Carbon Formation. One Earth, 2 (4), 349-360. doi: 10.1016/j.oneear.2020.03.006

Bai, E., Li, S., Xu, W., Li, W., Dai, W., \& Jiang, P. (2013). A meta-analysis of experimental warming effects on terrestrial nitrogen pools and dynamics. New Phytologist, 199 (2), 441-451. doi:10.1111/nph.12252

Byrne, B. (2016). Structural Equation Modeling With AMOS. New York: Routledge, https://doi.org/10.4324/9781315757421

Boothroyd, I. M., Worrall, F., \& Allott, T. E. H. (2015). Variations in dissolved organic carbon concentrations across peatland hillslopes.Journal of Hydrology, 530 , 372-383. doi: 10.1016/j.jhydrol.2015.10.002

Borken, W., \& Matzner, E. (2009). Reappraisal of drying and wetting effects on C and N mineralization and fluxes in soils. Global Change Biology, 15 (4), 808-824. doi:10.1111/j.1365-2486.2008.01681.x

Bouwman, A. (1990). Exchange of greenhouse gases between terrestrial ecosystems and the atmosphere. Soils and Greenhouse Effect .

Breiman, L. (2001). Random Forests. Machine Learning, 45 (1), 5-32. doi:10.1023/A:1010933404324

Butterbach-Bahl, K., Baggs, E. M., Dannenmann, M., Kiese, R., \& Zechmeister-Boltenstern, S. (2013). Nitrous oxide emissions from soils: how well do we understand the processes and their controls? Philosophical Transactions of the Royal Society B: Biological Sciences, 368 (1621), 20130122. doi: 10.1098/rstb.2013.0122

Cai, Y., \& Chang, S. (2020). Disturbance Effects on Soil Carbon and Greenhouse Gas Emissions in Forest Ecosystems. Forests, 11 , 297. doi:10.3390/f11030297

Cao, R., Chen, Y., Wu, X., Zhou, Q., \& Sun, S. (2018). The effect of drainage on CO2, CH4 and N2O emissions in the Zoige peatland: a 40-month in situ study. Mires and Peat, 21 , 15. doi:10.19189/MaP.2017.OMB.292

Chapman, E. J., Cadillo-Quiroz, H., Childers, D. L., Turetsky, M. R., \& Waldrop, M. P. (2017). Soil microbial community composition is correlated to soil carbon processing along a boreal wetland formation gradient. European Journal of Soil Biology, 82 , 17-26. doi: 10.1016/j.ejsobi.2017.08.001

Chapuis-Lardy, L., Wrage, N., Metay, A., Chotte, J.-L., \& Bernoux, M. (2007). Soils, a sink for N2O? A review. Global Change Biology, 13 (1), 1-17. doi:10.1111/j.1365-2486.2006.01280.x 
Chen, H., Yang, G., Peng, C., Zhang, Y., Zhu, D., Zhu, Q., . . Wu, J. (2014). The carbon stock of alpine peatlands on the Qinghai-Tibetan Plateau during the Holocene and their future fate. Quaternary Science Reviews, 95 , 151-158. doi: 10.1016/j.quascirev.2014.05.003

Chen, X., Hu, Y., Feng, S., Rui, Y., Zhang, Z., He, H., . . Su, Y. (2018). Lignin and cellulose dynamics with straw incorporation in two contrasting cropping soils. Scientific Reports, 8 (1), 1633. doi:10.1038/s41598018-20134-5

Chen, X., Wang, G., Zhang, T., Mao, T., Wei, D., Song, C., . . Huang, K. (2017). Effects of warming and nitrogen fertilization on GHG flux in an alpine swamp meadow of a permafrost region. Science of The Total Environment, 601-602 , 1389-1399. doi:10.1016/j.scitotenv.2017.06.028

Chen, Y. T., Borken, W., Stange, C. F., \& Matzner, E. (2012). Dynamics of Nitrogen and Carbon Mineralization in a Fen Soil Following Water Table Fluctuations. Wetlands, 32 (3), 579-587. doi:10.1007/s13157012-0295-7

Chimner, R. A., Pypker, T. G., Hribljan, J. A., Moore, P. A., \& Waddington, J. M. (2017). Multidecadal Changes in Water Table Levels Alter Peatland Carbon Cycling. Ecosystems, 20 (5), 1042-1057. doi:10.1007/s10021-016-0092-x

Craine, J. M., Fierer, N., \& McLauchlan, K. K. (2010). Widespread coupling between the rate and temperature sensitivity of organic matter decay. Nature Geoscience, 3 (12), 854-857. doi:10.1038/ngeo1009

Cui, Q., Song, C., Wang, X., Shi, F., Yu, X., \& Tan, W. (2018). Effects of warming on N2O fluxes in a boreal peatland of Permafrost region, Northeast China. Science of The Total Environment, 616 , 427-434. doi:10.1016/j.scitotenv.2017.10.246

Danevčič, T., Mandic-Mulec, I., Stres, B., Stopar, D., \& Hacin, J. (2010). Emissions of CO2, CH4 and N2O from Southern European peatlands.Soil Biology and Biochemistry, 42 (9), 1437-1446. doi: 10.1016/j.soilbio.2010.05.004

de Vries, F. T., Griffiths, R. I., Bailey, M., Craig, H., Girlanda, M., Gweon, H. S., . . . Bardgett, R. D. (2018). Soil bacterial networks are less stable under drought than fungal networks. Nature Communications, 9 (1), 3033. doi:10.1038/s41467-018-05516-7

Dedysh, S. (2011). Cultivating Uncultured Bacteria from Northern Wetlands: Knowledge Gained and Remaining Gaps. Frontiers in Microbiology, 2 (184). doi:10.3389/fmicb.2011.00184

Di Lonardo, D. P., De Boer, W., Klein Gunnewiek, P. J. A., Hannula, S. E., \& Van der Wal, A. (2017). Priming of soil organic matter: Chemical structure of added compounds is more important than the energy content.Soil Biology and Biochemistry, 108 , 41-54. doi: 10.1016/j.soilbio.2017.01.017

Dillon, M. E., Wang, G., \& Huey, R. B. (2010). Global metabolic impacts of recent climate warming. Nature, 467 (7316), 704-706. doi:10.1038/nature09407

Dise, N. B., \& Phoenix, G. K. (2011). Peatlands in a changing world.New Phytologist, 191(2), 309-311. doi:10.1111/j.1469-8137.2011.03801.x

Dong, Z., Hu, G., Yan, C., Wang, W., \& Lu, J. (2010). Aeolian desertification and its causes in the Zoige Plateau of China's Qinghai-Tibetan Plateau. Environmental Earth Sciences, 59 (8), 1731-1740. doi:10.1007/s12665-009-0155-9

Duval, T. P., \& Radu, D. D. (2018). Effect of temperature and soil organic matter quality on greenhouse-gas production from temperate poor and rich fen soils. Ecological Engineering, 114 , 66-75. doi:10.1016/j.ecoleng.2017.05.011

Eriksson, T., Öquist, M. G., \& Nilsson, M. B. (2010). Effects of decadal deposition of nitrogen and sulfur, and increased temperature, on methane emissions from a boreal peatland. Journal of Geophysical Research: Biogeosciences, 115 (G4). doi:10.1029/2010jg001285 
Fenner, N., \& Freeman, C. (2011). Drought-induced carbon loss in peatlands. Nature Geoscience, 4 (12), 895-900. doi:10.1038/ngeo1323

Freeman, C., Lock, M. A., \& Reynolds, B. (1992). Fluxes of CO2, CH4 and N2O from a Welsh peatland following simulation of water table draw-down: Potential feedback to climatic change. Biogeochemistry, 19 (1), 51-60. doi:10.1007/BF00000574

Gatis, N., Grand-Clement, E., Luscombe, D. J., Hartley, I. P., Anderson, K., \& Brazier, R. E. (2019). Growing season CO2 fluxes from a drained peatland dominated by Molinia caerulea. Mires and Peat, 24 . doi:10.19189/MaP.2019.OMB.StA.1812

Gill, A. L., Giasson, M.-A., Yu, R., \& Finzi, A. C. (2017). Deep peat warming increases surface methane and carbon dioxide emissions in a black spruce-dominated ombrotrophic bog. Global Change Biology, 23 (12), 5398-5411. doi:10.1111/gcb.13806

Gong, Y., Wu, J., Vogt, J., \& Le, T. B. (2019). Warming reduces the increase in N2O emission under nitrogen fertilization in a boreal peatland. Science of The Total Environment, 664, 72-78. doi:https://doi.org/10.1016/j.scitotenv.2019.02.012

Goodfellow, M., \& Williams, S. T. (1983). Ecology of actinomycetes.Annu Rev Microbiol, 37, 189-216. doi:10.1146/annurev.mi.37.100183.001201

Grace, J. B. (2006). Structural Equation Modeling and Natural Systems . Cambridge: Cambridge University Press.

Hanson, R. S., \& Hanson, T. E. (1996). Methanotrophic bacteria.Microbiological Reviews, 60 (2), 439-471.

Holden, J., Chapman, P. J., Lane, S. N., \& Brookes, C. (2006). Chapter 22 Impacts of artificial drainage of peatlands on runoff production and water quality. In I. P. Martini, A. Martínez Cortizas, \& W. Chesworth (Eds.), Developments in Earth Surface Processes (Vol. 9, pp. 501-528): Elsevier.

Hooijer, A., Page, S., Canadell, J., Silvius, M., Kwadijk, J., Wösten, H., \& Jauhiainen, J. (2010). Current and future CO2 emissions from drained peatlands in Southeast Asia. Biogeosciences . doi:10.5194/bg-7-1505-2010

Hopple, A. M., Wilson, R. M., Kolton, M., Zalman, C. A., Chanton, J. P., Kostka, J., . . Bridgham, S. D. (2020). Massive peatland carbon banks vulnerable to rising temperatures. Nature Communications, 11 (1), 2373-2373. doi:10.1038/s41467-020-16311-8

Hou, C., Song, C., Li, Y., Wang, J., Song, Y., \& Wang, X. (2013). Effects of water table changes on soil $\mathrm{CO} 2, \mathrm{CH} 4$ and $\mathrm{N} 2 \mathrm{O}$ fluxes during the growing season in freshwater marsh of Northeast China.Environmental Earth Sciences, 69 (6), 1963-1971. doi:10.1007/s12665-012-2031-2

Huang, Y., Zou, J., Zheng, X., Wang, Y., \& Xu, X. (2004). Nitrous oxide emissions as influenced by amendment of plant residues with different C:N ratios. Soil Biology and Biochemistry, 36 (6), 973-981. doi: $10.1016 /$ j.soilbio.2004.02.009

Ise, T., Dunn, A. L., Wofsy, S. C., \& Moorcroft, P. R. (2008). High sensitivity of peat decomposition to climate change through water-table feedback. Nature Geoscience, 1(11), 763-766. doi:10.1038/ngeo331

Jaatinen, K., Fritze, H., Laine, J., \& Laiho, R. (2007). Effects of short- and long-term water-level drawdown on the populations and activity of aerobic decomposers in a boreal peatland. Global Change Biology, 13 (2), 491-510. doi:10.1111/j.1365-2486.2006.01312.x

Jaatinen, K., Laiho, R., Vuorenmaa, A., Del Castillo, U., Minkkinen, K., Pennanen, T., . . Fritze, H. (2008). Responses of aerobic microbial communities and soil respiration to water-level drawdown in a northern boreal fen. Environmental Microbiology, 10 (2), 339-353. doi:10.1111/j.1462-2920.2007.01455.x

Jaatinen, K., Laiho, R., Vuorenmaa, A., del Castillo, U., Minkkinen, K., Pennanen, T., . . Fritze, H. (2008). Responses of aerobic microbial communities and soil respiration to water-level drawdown in a northern boreal 
fen. Environ Microbiol, 10 (2), 339-353. doi:10.1111/j.1462-2920.2007.01455.x

Johnson, C. P., Pypker, T. G., Hribljan, J. A., \& Chimner, R. A. (2013). Open Top Chambers and Infrared Lamps: A Comparison of Heating Efficacy and CO2/CH4 Dynamics in a Northern Michigan Peatland.Ecosystems, 16 (5), 736-748. doi:10.1007/s10021-013-9646-3

Kang, X., Yan, L., Cui, L., Zhang, X., Hao, Y., Wu, H., . . Wang, J. (2018). Reduced Carbon Dioxide Sink and Methane Source under Extreme Drought Condition in an Alpine Peatland. Sustainability, 10 , 4285. doi:10.3390/su10114285

Knorr, K. H., Glaser, B., \& Blodau, C. (2008). Fluxes and 13C isotopic composition of dissolved carbon and pathways of methanogenesis in a fen soil exposed to experimental drought. Biogeosciences, 5 (5), 1457-1473. doi:10.5194/bg-5-1457-2008

Knowles, R. (1982). Denitrification. Microbiological Reviews, 46 (1), 43-70.

Kwon, M. J., Haraguchi, A., \& Kang, H. (2013). Long-term water regime differentiates changes in decomposition and microbial properties in tropical peat soils exposed to the short-term drought. Soil Biology and Biochemistry, 60 , 33-44. doi:10.1016/j.soilbio.2013.01.023

Laiho, R. (2006). Decomposition in peatlands: Reconciling seemingly contrasting results on the impacts of lowered water levels. Soil Biology and Biochemistry, 38 (8), 2011-2024. doi: 10.1016/j.soilbio.2006.02.017

Laiho, R., Silvan, N., Cárcamo, H., \& Vasander, H. (2001). Effects of water level and nutrients on spatial distribution of soil mesofauna in peatlands drained for forestry in Finland. Applied Soil Ecology, 16 (1), 1-9. doi:10.1016/S0929-1393(00)00103-7

Laine, A. M., Makiranta, P., Laiho, R., Mehtatalo, L., Penttila, T., Korrensalo, A., . . Tuittila, E.-S. (2019). Warming impacts on boreal fen CO2 exchange under wet and dry conditions. Global Change Biology, 25 (6), 1995-2008. doi:10.1111/gcb.14617

Laine, A. M., Mehtatalo, L., Tolvanen, A., Frolking, S., \& Tuittila, E. S. (2019). Impacts of drainage, restoration and warming on boreal wetland greenhouse gas fluxes. Science of The Total Environment, 647, 169-181. doi:10.1016/j.scitotenv.2018.07.390

Laine, J., Silvola, Tolonen, K., Alm, J., Nykänen, H., Vasander, H., . . Martikainen, P. (1996). Effect of water-level drawdown on global climatic warming: Northern peatlands. Ambio, 25 .

Leifeld, J., Steffens, M., \& Galego-Sala, A. (2012). Sensitivity of peatland carbon loss to organic matter quality. Geophysical Research Letters, 39 (14). doi:10.1029/2012gl051856

Leifeld, J., Wüst-Galley, C., \& Page, S. (2019). Intact and managed peatland soils as a source and sink of GHGs from 1850 to 2100.Nature Climate Change, 9 (12), 945-947. doi:10.1038/s41558-019-0615-5

Liu, L., Chen, H., Jiang, L., Zhan, W., Hu, J., He, Y., . . Yang, G. (2019). Response of anaerobic mineralization of different depths peat carbon to warming on Zoige plateau. Geoderma, 337, 1218-1226. doi: 10.1016/j.geoderma.2018.10.031

Liu, L., Chen, H., Zhu, Q., Yang, G., Zhu, E., Hu, J., . . . Zhu, D. (2016). Responses of peat carbon at different depths to simulated warming and oxidizing. Science of The Total Environment, 548-549 , 429-440. doi: 10.1016/j.scitotenv.2015.11.149

Louca, S., Parfrey, L. W., \& Doebeli, M. (2016). Decoupling function and taxonomy in the global ocean microbiome. Science, 353 (6305), 1272. doi:10.1126/science.aaf4507

Ludley, K., \& Robinson, C. (2008). 'Decomposer' Basidiomycota in Arctic and Antarctic ecosystems. Soil Biology and Biochemistry, 40 , 11-29. doi:10.1016/j.soilbio.2007.07.023

Maljanen, M., Hytönen, J., \& Martikainen, P. J. (2001). Fluxes of N2O, CH4 and CO2 on afforested boreal agricultural soils. Plant and Soil, 231 (1), 113-121. doi:10.1023/A:1010372914805 
Martikainen, P. J., Nykänen, H., Crill, P., \& Silvola, J. (1993). Effect of a lowered water table on nitrous oxide fluxes from northern peatlands. Nature, 366 (6450), 51-53. doi:10.1038/366051a0

McPartland, M. Y., Kane, E. S., Falkowski, M. J., Kolka, R., Turetsky, M. R., Palik, B., \& Montgomery, R. A. (2019). The response of boreal peatland community composition and NDVI to hydrologic change, warming, and elevated carbon dioxide. Global Change Biology, 25 (1), 93-107. doi:10.1111/gcb.14465

Miller, C., Benscoter, B., \& Turetsky, M. (2015). The effect of long-term drying associated with experimental drainage and road construction on vegetation composition and productivity in boreal fens. Wetlands Ecology and Management, 23 . doi:10.1007/s11273-015-9423-5

Minick, K. J., Mitra, B., Li, X., Noormets, A., \& King, J. S. (2019). Water Table Drawdown Alters Soil and Microbial Carbon Pool Size and Isotope Composition in Coastal Freshwater Forested Wetlands.Frontiers in Forests and Global Change, 2 (7). doi:10.3389/ffgc.2019.00007

Mpamah, P. A., Taipale, S., Rissanen, A. J., Biasi, C., \& Nykanen, H. K. (2017). The impact of long-term water level draw-down on microbial biomass: A comparative study from two peatland sites with different nutrient status. European Journal of Soil Biology, 80 , 59-68. doi:10.1016/j.ejsobi.2017.04.005

Muhr, J., Höhle, J., Otieno, D. O., \& Borken, W. (2011). Manipulative lowering of the water table during summer does not affect CO2 emissions and uptake in a fen in Germany. Ecological Applications, 21 (2), 391-401. doi:10.1890/09-1251.1

Munir, T. M., \& Strack, M. (2014). Methane Flux Influenced by Experimental Water Table Drawdown and Soil Warming in a Dry Boreal Continental Bog. Ecosystems, 17 (7), 1271-1285. doi:10.1007/s10021-0149795-Z

Murphy, M., Laiho, R., \& Moore, T. R. (2009). Effects of Water Table Drawdown on Root Production and Aboveground Biomass in a Boreal Bog.Ecosystems, 12 (8), 1268-1282. doi:10.1007/s10021-009-9283-z

Nichols, J. E., \& Peteet, D. M. (2019). Rapid expansion of northern peatlands and doubled estimate of carbon storage. Nature Geoscience, 12 (11), 917-921. doi:10.1038/s41561-019-0454-z

Nieveen, J. P., Campbell, D. I., Schipper, L. A., \& Blair, I. J. (2005). Carbon exchange of grazed pasture on a drained peat soil.Global Change Biology, 11 (4), 607-618. doi:10.1111/j.1365-2486.2005.00929.x

Norberg, L., Berglund, Ö., \& Berglund, K. (2018). Impact of drainage and soil properties on carbon dioxide emissions from intact cores of cultivated peat soils. Mires and Peat, 21 . doi:10.19189/MaP.2017.OMB.284

Oertel, C., Matschullat, J., Zurba, K., Zimmermann, F., \& Erasmi, S. (2016). Greenhouse gas emissions from soils-A review. Geochemistry, 76 (3), 327-352. doi: 10.1016/j.chemer.2016.04.002

Pal, L., Stres, B., Danevčič, T., Leskovec, S., \& Mandic-Mulec, I. (2010). Transformations of mineral nitrogen applied to peat soil during sequential oxic/anoxic cycling. Soil Biology and Biochemistry, 42 (8), 1338-1346. doi: $10.1016 /$ j.soilbio.2010.03.013

Pankratov, T., Dedysh, S., \& Zavarzin, G. A. (2006). The leading role of actinobacteria in aerobic cellulose degradation in Sphagnum peat bogs. Doklady Biological Sciences, 410 , 428-430. doi:10.1134/S0012496606050243

Pearson, M., Penttilä, T., Harjunpää, L., Laiho, R., Laine, J., Sarjala, T., . . . Silvan, N. (2015). Effects of temperature rise and water-table-level drawdown on greenhouse gas fluxes of boreal sedge fens. Boreal Environment Research, 20 , 489-505.

Peltoniemi, K., Fritze, H., \& Laiho, R. (2009). Response of fungal and actinobacterial communities to water-level drawdown in boreal peatland sites. Soil Biology and Biochemistry, 41 (9), 1902-1914. doi:10.1016/j.soilbio.2009.06.018 
Peltoniemi, K., Laiho, R., Juottonen, H., Bodrossy, L., Kell, D. K., Minkkinen, K., . . Fritze, H. (2016). Responses of methanogenic and methanotrophic communities to warming in varying moisture regimes of two boreal fens. Soil Biology and Biochemistry, 97 , 144-156. doi:10.1016/j.soilbio.2016.03.007

Peng, H.-Y., Li, X.-Y., Li, G.-Y., Zhang, Z.-H., Zhang, S.-Y., Li, L., . . Ma, Y.-J. (2013). Shrub encroachment with increasing anthropogenic disturbance in the semiarid Inner Mongolian grasslands of China.CATENA, 109 , 39-48. doi: 10.1016/j.catena.2013.05.008

Qiu, J. (2007). Riding on the roof of the world. Nature, 449 (7161), 398-402. doi:10.1038/449398a

R Core Team (2018) R: A Language and Environment for Statistical Computing. R Foundation for Statistical Computing, Vienna.https://www.R-project.org

Regina, K., Silvola, J., \& Martikainen, P. J. (1999). Short-term effects of changing water table on N2O fluxes from peat monoliths from natural and drained boreal peatlands. Global Change Biology, 5 (2), 183-189. doi:10.1046/j.1365-2486.1999.00217.x

Ren, M., Zhang, Z., Wang, X., Zhou, Z., Chen, D., Zeng, H., . . . Peng, N. (2018). Diversity and Contributions to Nitrogen Cycling and Carbon Fixation of Soil Salinity Shaped Microbial Communities in Tarim Basin.Frontiers in Microbiology, 9 , 431-431. doi:10.3389/fmicb.2018.00431

Rhymes, J., Jones, L., Wallace, H., Jones, T. G., Dunn, C., \& Fenner, N. (2016). Small changes in water levels and groundwater nutrients alter nitrogen and carbon processing in dune slack soils. Soil Biology and Biochemistry, 99 , 28-35. doi:10.1016/j.soilbio.2016.04.018

Salm, J.-O., Kimmel, K., Uri, V., \& Mander, U. (2009). Global warming potential of drained and undrained peatlands in estonia: A synthesis. Wetlands, 29 (4), 1081-1092. doi:10.1672/08-206.1

Saurich, A., Tiemeyer, B., Dettmann, U., \& Don, A. (2019). How do sand addition, soil moisture and nutrient status influence greenhouse gas fluxes from drained organic soils? Soil Biology and Biochemistry, 135 , 71-84. doi:10.1016/j.soilbio.2019.04.013

Schimel, J. P., \& Gulledge, J. A. Y. (1998). Microbial community structure and global trace gases. Global Change Biology, 4 (7), 745-758. doi:10.1046/j.1365-2486.1998.00195.x

Schnecker, J., Wild, B., Takriti, M., Eloy Alves, R. J., Gentsch, N., Gittel, A., . . . Richter, A. (2015). Microbial community composition shapes enzyme patterns in topsoil and subsoil horizons along a latitudinal transect in Western Siberia. Soil Biology and Biochemistry, 83 , 106-115. doi: 10.1016/j.soilbio.2015.01.016

Siljanen, H. M. P., Saari, A., Bodrossy, L., \& Martikainen, P. J. (2012). Seasonal variation in the function and diversity of methanotrophs in the littoral wetland of a boreal eutrophic lake.FEMS Microbiology Ecology, 80 (3), 548-555. doi:10.1111/j.1574-6941.2012.01321.x

Singh, B. K., Bardgett, R. D., Smith, P., \& Reay, D. S. (2010). Microorganisms and climate change: terrestrial feedbacks and mitigation options. Nature Reviews Microbiology, 8 (11), 779-790. doi:10.1038/nrmicro2439

Swails, E., Jaye, D., Verchot, L., Hergoualc'h, K., Schirrmann, M., Borchard, N., . . Lawrence, D. (2018). Will CO2 Emissions from Drained Tropical Peatlands Decline Over Time? Links Between Soil Organic Matter Quality, Nutrients, and C Mineralization Rates. Ecosystems, 21 (5), 868-885. doi:10.1007/s10021-017-0190-4

Thompson, J., Johansen, R., Dunbar, J., \& Munsky, B. (2019). Machine learning to predict microbial community functions: An analysis of dissolved organic carbon from litter decomposition. PLOS ONE, 14 (7), e0215502. doi:10.1371/journal.pone.0215502

Tiemeyer, B., Albiac Borraz, E., Augustin, J., Bechtold, M., Beetz, S., Beyer, C., . . Z Zeitz, J. (2016). High emissions of greenhouse gases from grasslands on peat and other organic soils. Global Change Biology, 22 (12), 4134-4149. doi:10.1111/gcb.13303 
Turetsky, M. R., Treat, C. C., Waldrop, M. P., Waddington, J. M., Harden, J. W., \& McGuire, A. D. (2008). Short-term response of methane fluxes and methanogen activity to water table and soil warming manipulations in an Alaskan peatland. Journal of Geophysical Research: Biogeosciences, 113 (G3). doi:10.1029/2007jg000496

Urbanova, Z., \& Barta, J. (2016). Effects of long-term drainage on microbial community composition vary between peatland types. Soil Biology and Biochemistry, 92 , 16-26. doi:10.1016/j.soilbio.2015.09.017

van den Berg, L. J. L., Shotbolt, L., \& Ashmore, M. R. (2012). Dissolved organic carbon (DOC) concentrations in UK soils and the influence of soil, vegetation type and seasonality. Science of The Total Environment, 427-428, 269-276. doi: 10.1016/j.scitotenv.2012.03.069

Voigt, C., Lamprecht, R. E., Marushchak, M. E., Lind, S. E., Novakovskiy, A., Aurela, M., . . Biasi, C. (2017). Warming of subarctic tundra increases emissions of all three important greenhouse gases - carbon dioxide, methane, and nitrous oxide. Global Change Biology, 23 (8), 3121-3138. doi:10.1111/gcb.13563

Voigt, C., Marushchak, M. E., Lamprecht, R. E., Jackowicz-Korczyński, M., Lindgren, A., Mastepanov, M., . . . Biasi, C. (2017). Increased nitrous oxide emissions from Arctic peatlands after permafrost thaw.Proceedings of the National Academy of Sciences, 114 (24), 6238. doi:10.1073/pnas.1702902114

Wang, H., Yu, L., Zhang, Z., Liu, W., Chen, L., Cao, G., . . . He, J.-S. (2017). Molecular mechanisms of water table lowering and nitrogen deposition in affecting greenhouse gas emissions from a Tibetan alpine wetland. Global Change Biology, 23 (2), 815-829. doi:10.1111/gcb.13467

Wang, X., Siciliano, S., Helgason, B., \& Bedard-Haughn, A. (2017). Responses of a mountain peatland to increasing temperature: A microcosm study of greenhouse gas emissions and microbial community dynamics.Soil Biology and Biochemistry, 110 , 22-33. doi: 10.1016/j.soilbio.2017.02.013

Ward, S. E., Bardgett, R. D., McNamara, N. P., Adamson, J. K., \& Ostle, N. J. (2007). Long-Term Consequences of Grazing and Burning on Northern Peatland Carbon Dynamics. Ecosystems, 10 (7), 10691083. doi:10.1007/s10021-007-9080-5

Weedon, J. T., Aerts, R., Kowalchuk, G. A., van Logtestijn, R., Andringa, D., \& van Bodegom, P. M. (2013). Temperature sensitivity of peatland $\mathrm{C}$ and $\mathrm{N}$ cycling: Does substrate supply play a role? Soil Biology and Biochemistry, 61, 109-120. doi:https://doi.org/10.1016/j.soilbio.2013.02.019

Weil, R., \& Brady, N. (2017). The Nature and Properties of Soils. 15th edition .

Wen, Y., Zang, H., Freeman, B., Musarika, S., Evans, C. D., Chadwick, D. R., \& Jones, D. L. (2019). Microbial utilization of low molecular weight organic carbon substrates in cultivated peats in response to warming and soil degradation. Soil Biology and Biochemistry, 139 . doi:10.1016/j.soilbio.2019.107629

Wiedermann, M. M., Kane, E. S., Potvin, L. R., \& Lilleskov, E. A. (2017). Interactive plant functional group and water table effects on decomposition and extracellular enzyme activity in Sphagnum peatlands.Soil Biology and Biochemistry, 108 , 1-8. doi: 10.1016/j.soilbio.2017.01.008

Xue, D., Chen, H., Chen, F., He, Y., Zhao, C., Zhu, D., . . . Li, W. (2016). Analysis of the rumen bacteria and methanogenic archaea of yak (Bos grunniens) steers grazing on the Qinghai-Tibetan Plateau.Livestock Science, 188, 61-71. doi:https://doi.org/10.1016/j.livsci.2016.04.009

Yang, G., Chen, H., Wu, N., Tian, J., Peng, C., Zhu, Q., . . . Zhang, C. (2014). Effects of soil warming, rainfall reduction and water table level on $\mathrm{CH} 4$ emissions from the Zoige peatland in China. Soil Biology and Biochemistry, 78 , 83-89. doi: 10.1016/j.soilbio.2014.07.013

Zhang, G. S., Yu, X. B., Gao, Y., Li, Y., Zhang, Q. J., Liu, Y., . . . Xia, S. X. (2018). Effects of water table on cellulose and lignin degradation of Carex cinerascens in a large seasonal floodplain. Journal of Freshwater Ecology, 33 (1), 311-325. doi:10.1080/02705060.2018.1459324 
Zhang, J., Liu, Y.-X., Zhang, N., Hu, B., Jin, T., Xu, H., . . . Bai, Y. (2019). NRT1.1B is associated with root microbiota composition and nitrogen use in field-grown rice. Nature Biotechnology, 37 (6), 676-684. doi:10.1038/s41587-019-0104-4

Zhang, W., Wang, J., Hu, Z., Li, Y., Yan, Z., Zhang, X., . . . Kang, X. (2020). The Primary Drivers of Greenhouse Gas Emissions Along the Water Table Gradient in the Zoige Alpine Peatland. Water Air and Soil Pollution, 231 (5). doi:10.1007/s11270-020-04605-y

Zhong, Q., Chen, H., Liu, L., He, Y., Zhu, D., Jiang, L., . . . Hu, J. (2017). Water table drawdown shapes the depth-dependent variations in prokaryotic diversity and structure in Zoige peatlands. FEMS Microbiology Ecology, 93 (6). doi:10.1093/femsec/fix049

Zhong, Q., Xue, D., Chen, H., Liu, L., He, Y., Zhu, D., \& He, Z. (2020). Structure and distribution of nitrite-dependent anaerobic methane oxidation bacteria vary with water tables in Zoige peatlands.FEMS Microbiology Ecology, 96 (5). doi:10.1093/femsec/fiaa039

Zhou, W., Cui, L., Wang, Y., \& Li, W. (2017). Methane emissions from natural and drained peatlands in the Zoigê, eastern Qinghai-Tibet Plateau. Journal of Forestry Research, 28 (3), 539-547. doi:10.1007/s11676016-0343-x

\section{Table Captions}

Table S1. The relative abundance of Prokaryote and fungi at phylum level under different water table treatments in short-term and long-term drainage peatlands.

Table S2. The average GHG emission rate and temperature sensitivity $\left(\mathrm{Q}_{10}\right)$ of three different water table treatments in short- and long-term drainage peatlands under $8{ }^{\circ} \mathrm{C}$ and $18{ }^{\circ} \mathrm{C}$.

Table S3. Soil DOC and TDN concentration variations under different water table (WT) treatments in short-term and long-term drainage peatlands.

Table S4. Data on soil and plant properties in short-term and long-term drained peatlands.

Figure captions

\section{Figure 1. Map of sampling site (Ruokeba) in Zoige Plateau peatland}

Figure 2. The compositions and structures of prokaryotic (a,c) and fungal $(b, d)$ in peatlands with different drainage age and water table levels. S: Short-term drainage sites, L: Long-term drainage sites, S2 and L2: low water table treatment (LWT), S10 and L10: intermediate water table treatment (IWT), S50 and L50: high water table treatment (HWT).

Figure 3. Microbial biomarkers and predicted functional profiles of prokaryote with differen water table levels. (a) Top 14 prokaryotic families were identified by using random-forest classification of the relative abundance of prokaryote with different water table levels. (b) Heatmap of the relative abundance of biomarker families in the individual samples. (c) The differeces prokaryotic function in the FaProTax database for different water table treatments. S: Short-term drainage site, L: Long-term drainage site, S2 and L2: low water table treatment (LWT), S10 and L10: intermediate water table treatment (IWT), S50 and L50: high water table treatment (HWT).

Figure 4. The average GHG emission rate during 35d incubation in short- and long-term drainage peatlands with three different water table treatments under $8{ }^{\circ} \mathrm{C}$ and $18{ }^{\circ} \mathrm{C}$. (a) $\mathrm{CO}_{2}$ emissions; (b) $\mathrm{CH}_{4}$ emissions; (c) $\mathrm{N}_{2} \mathrm{O}$ emissions. Significance level: ${ }^{*} p<0.05,{ }^{* *} p<0.01$, or ${ }^{* * *} p<0.001$. S: Short-term drainage site, L: Long-term drainage site, S2 and L2: low water table treatment (LWT), S10 and L10: intermediate water table treatment (IWT), S50 and L50: high water table treatment (HWT).

Figure 5. Variation of DOC (a) and TDN (b) concentration of three different water table treatments in short- and long-term drainage peatlands under $8{ }^{\circ} \mathrm{C}$ and $18{ }^{\circ} \mathrm{C}$. Significance level: ${ }^{*} p<0.05,{ }^{* *} p<0.01$, or ${ }^{* * *} p<0.001$. S: Short-term drainage site, L: Long-term drainage site, S2 and L2: 
low water table treatment (LWT), S10 and L10: intermediate water table treatment (IWT), S50 and L50: high water table treatment (HWT).

Figure 6.Relationship between the average GHG emission and DOC(a, c, e) and TDN concentration $(\mathbf{b}, \mathbf{d}, \mathbf{f})$. Grey circle represents at $8{ }^{\circ} \mathrm{C}$, and red circle represents at $18{ }^{\circ} \mathrm{C}$.

Figure 7. Spearman's correlation analysis between the dominant microbial phyla and GHG emissions, DOCconcentration and TDN concentration. Grey font indicates fungal phyla, and black font indicates prokaryotic phyla. Significance level: ${ }^{*} p<0.05,{ }^{* *} p<0.01$, or ${ }^{* * *} p<0.001$.

Figure 8. The impacts of water table, drainage age, soil properties and soil prokaryotic and fungal communities on GHG emissions as estimated using the structural equation modeling.( a) $\mathrm{CO}_{2}$ emissions; (b) $\mathrm{CH}_{4}$ emissions; (c) $\mathrm{N}_{2} \mathrm{O}$ emissions. Standardized path coefficients are listed beside each path (Red and blue arrows represent positive and negative relationships, black double arrows represent covariant correlation; Paths with insignificant coefficients are represented using gray lines; ${ }^{*} p<0.05,{ }^{* *} p<0.01$, or $\left.{ }^{* * *} p<0.001\right)$. $\mathrm{R}^{2}$ values indicate the strength of explanation by independent variables. The prokaryotic and fungal diversities are represented using Shannon indexes, and the prokaryotic and fungal communities are represented using NMDS of the Bray-Curtis distance matrix.

Figure S1. Water table data at different distances from short- and long-term drainage ditches in recent three growing seasons (2016-2018). (a) The fluctuation of water table depth (WTD); (b) Average water table depths. S: Short-term drainage peatlands, L: Long-term drainage peatlands, S2 and L2: low water table treatment (LWT), S10 and L10: intermediate water table treatment (IWT), S50 and L50: high water table treatment (HWT).

Figure S2. Variation of GHG emission rate of soil from three different water table treatments in short- and long-term drainage peatlands under $8{ }^{\circ} \mathrm{C}$ and $18{ }^{\circ} \mathrm{C}$. (a) $\mathrm{CO}_{2}$ emission rate at $8^{\circ} \mathrm{C}$; (b) $\mathrm{CH} \backslash$ sout 4 emission rate at $8^{\circ} \mathrm{C}$; (c) $\mathrm{N}_{2} \mathrm{O}$ emission rate at $8^{\circ} \mathrm{C}$; (d) $\mathrm{CO}_{2}$ emission rate at $18^{\circ} \mathrm{C}$; (e) $\mathrm{CH}_{4}$ emission rate at $18^{\circ} \mathrm{C}$; (f) $\mathrm{N}_{2} \mathrm{O}$ emission rate at $18^{\circ} \mathrm{C}$.

Figure S3. Temperature sensitivity $\left(Q_{10}\right)$ value variations from three different water table treatments in short- and long-term drainage peatlands. (a) $\mathrm{CO}_{2}$; (b) $\mathrm{CH}_{4}$; (c) $\mathrm{N}_{2} \mathrm{O}$. Significance level: ${ }^{*} p<0.05,{ }^{* *} p<0.01$, or ${ }^{* * *} p<0.001$. S: Short-term drainage site, L: Long-term drainage site, S2 and L2: low water table treatment (LWT), S10 and L10: intermediate water table treatment (IWT), S50 and L50: high water table treatment (HWT).

Figure S4. Spearman's correlation analysis between GHG emissions and soil properties, soil prokaryotic and fungal communities. Significance level: ${ }^{*} p<0.05,{ }^{* *} p<0.01$, or ${ }^{* * *} p<0.001$. 
Figure 1

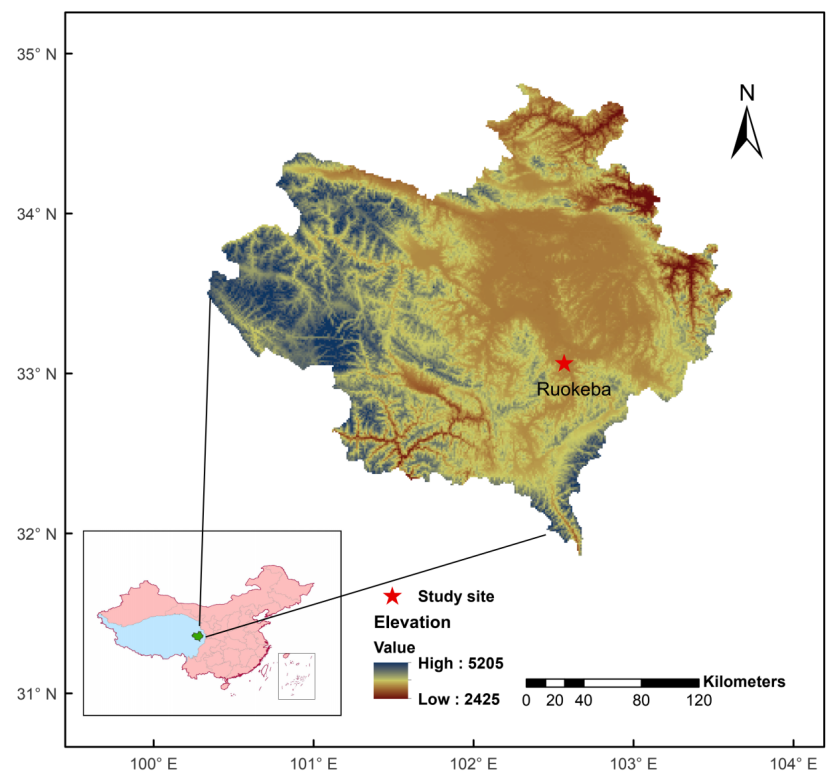

Figure 2

(a)
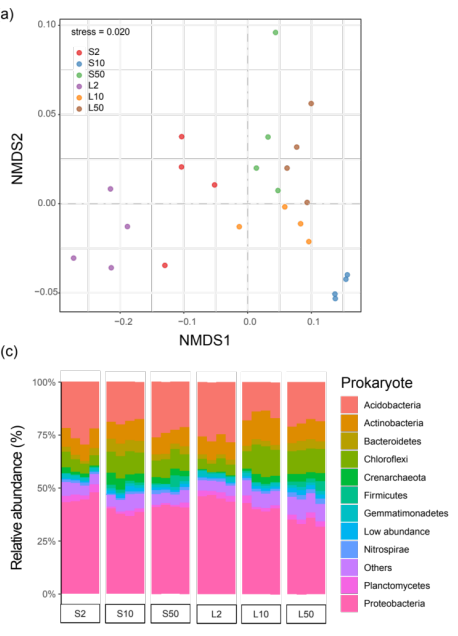
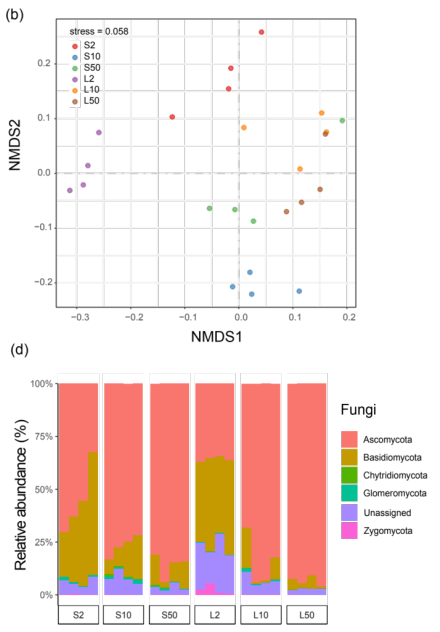
Figure 3

(a)

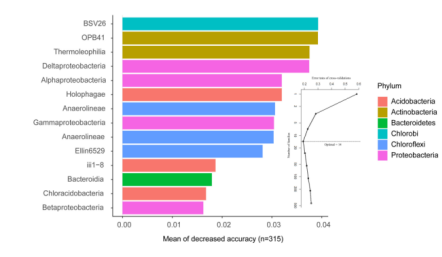

(b)

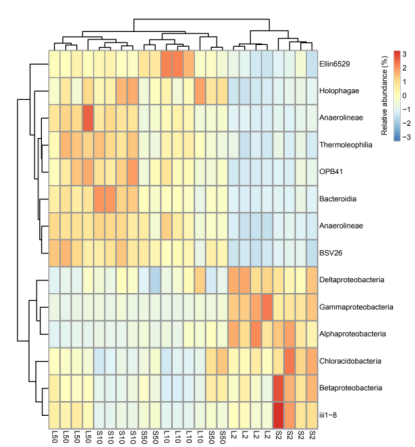

(c)

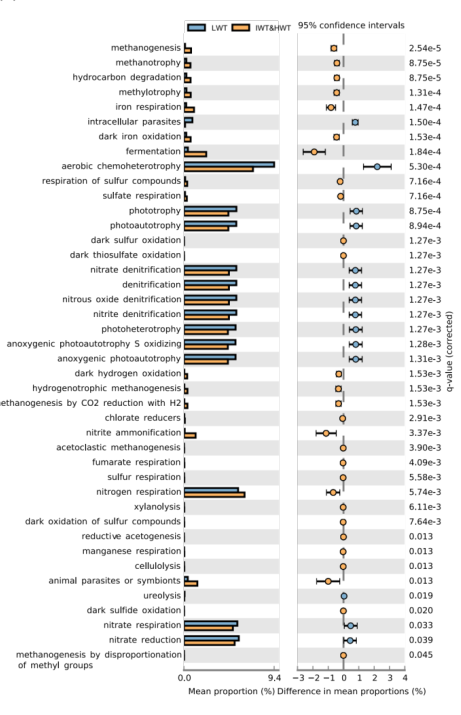


Figure 4
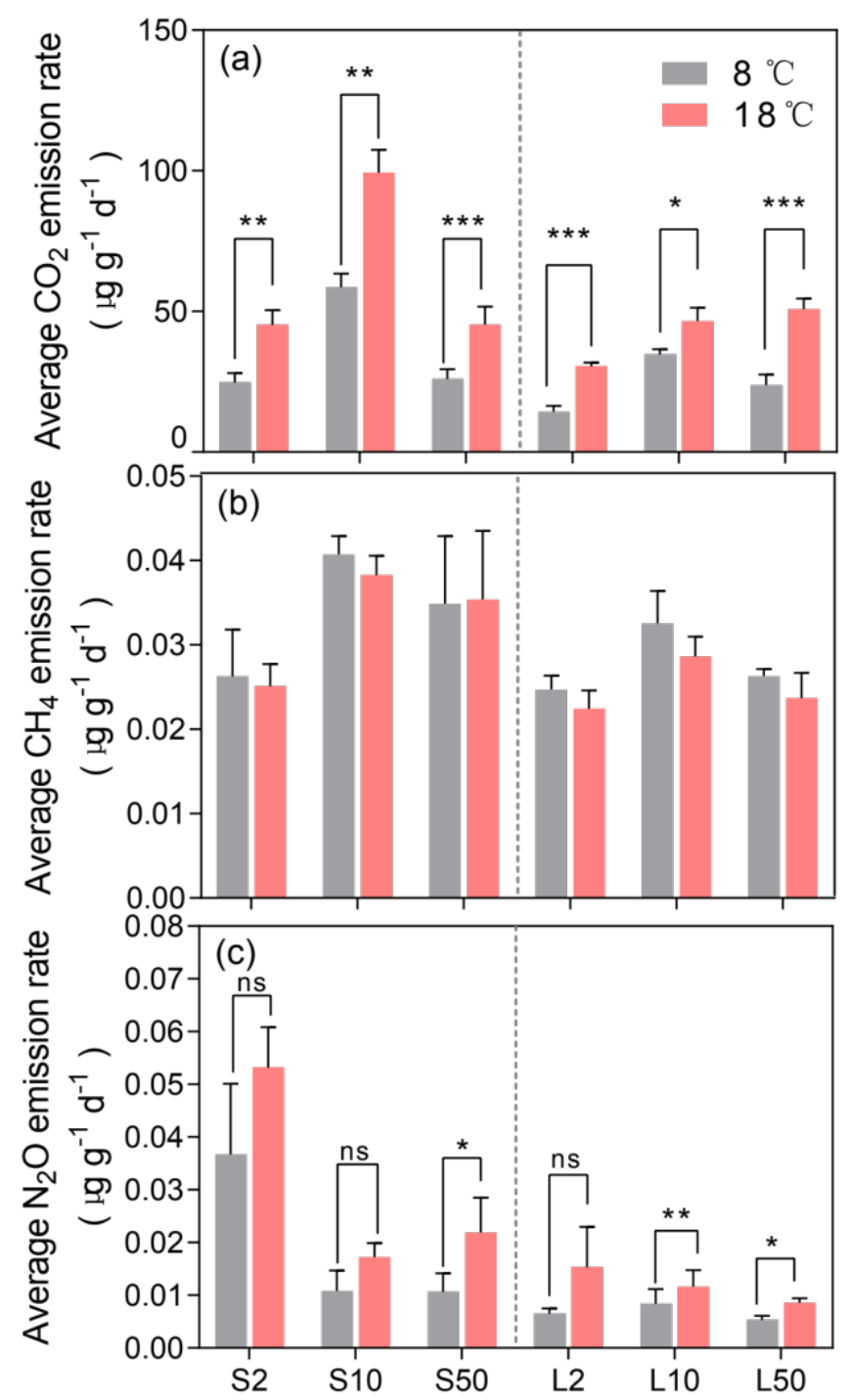
Figure 5

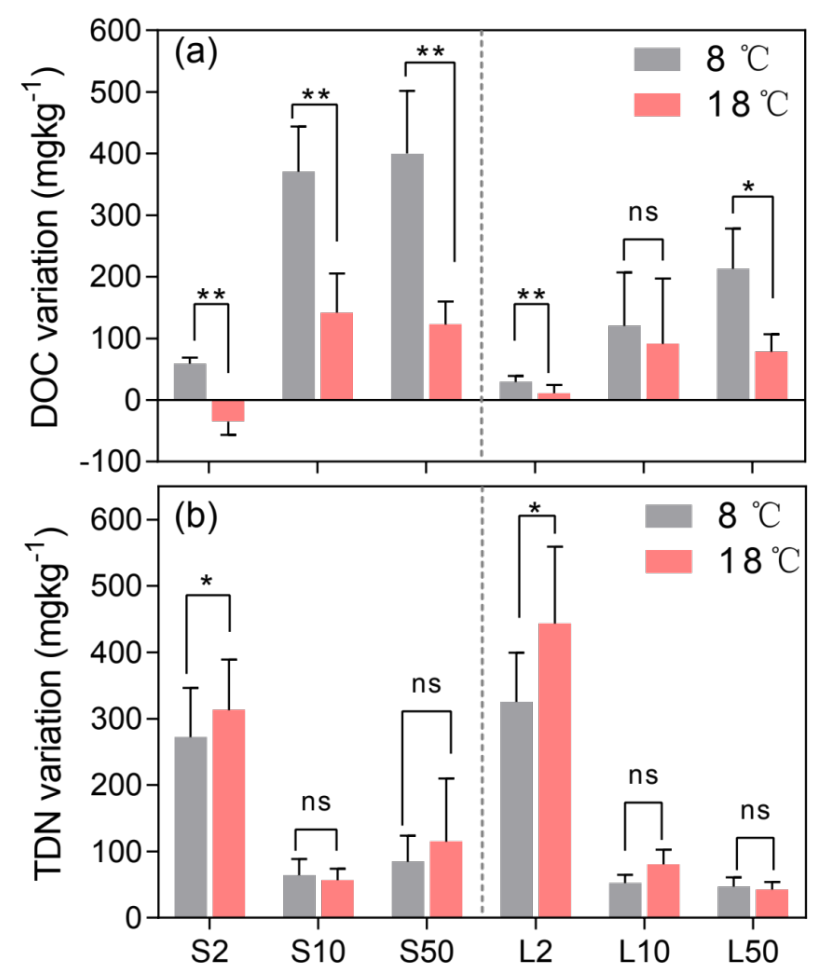


Figure 6
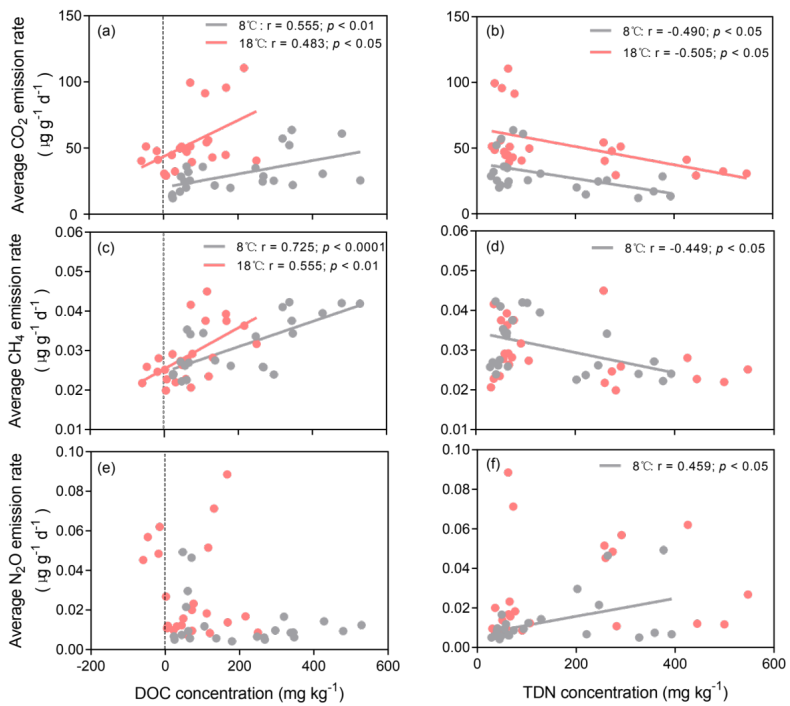

Figure 7

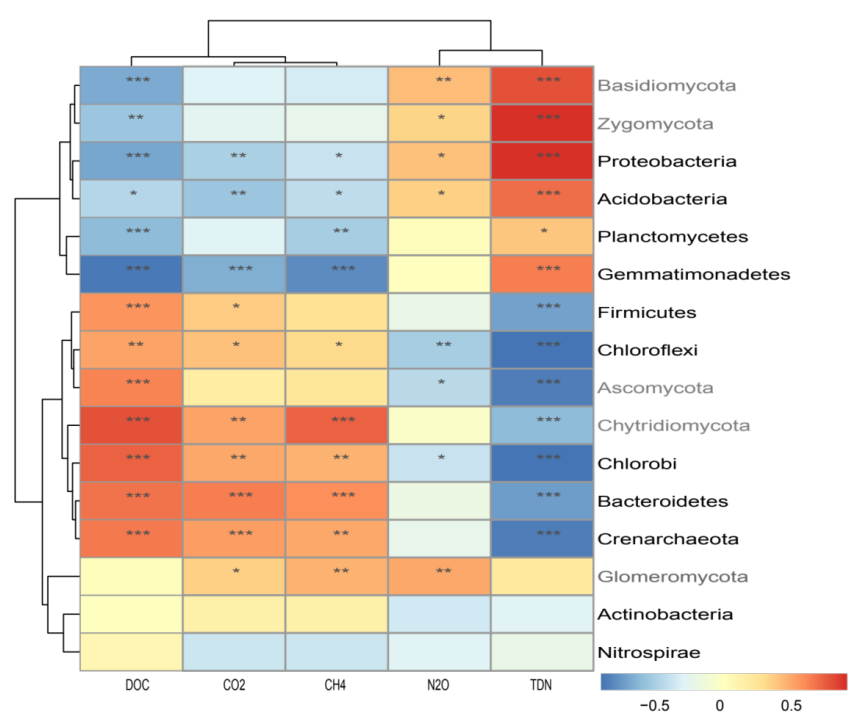


Figure 8

$\begin{array}{lll}\text { (a) } \mathrm{x} 2=16.164, \mathrm{df}=19, P=0.646, \mathrm{RMSEA}<0.001 & \text { (b) } \mathrm{x} 2=4.385, \mathrm{df}=7, P=0.735, \mathrm{RMSEA}<0.001 & \text { (c) } \mathrm{x} 2=4.671, \mathrm{df}=7, P=0.700, \mathrm{RMSEA}<0.001\end{array}$
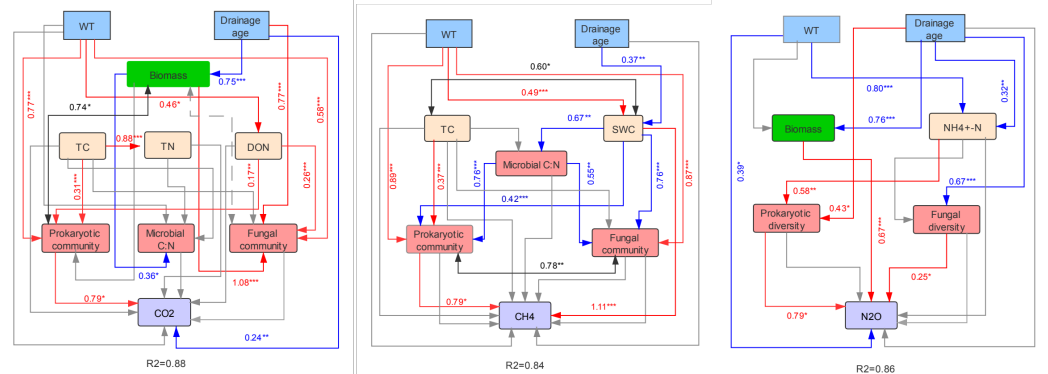